The Art of Life 
This page intentionally left blank. 


\section{The Art of Life}

Studies in American Autobiographical Literature

By Mutlu Konuk Blasing

University of Texas Press Austin \& London 
Permission to reprint material from the following works is gratefully acknowledged:

Chapter One, "The Economies of Walden," is reprinted in modified form from Texas Studies in Literature and Language 17, no. 4 (Winter 1976) : 759-775. Reprinted by permission of the University of Texas Press.

Collected Earlier Poems, by William Carlos Williams. (C) 1938 by New Directions Publishing Corp. Reprinted by permission of New Directions Publishing Corp.

Collected Later Poems, by William Carlos Williams. (C) 1944 by William Carlos Williams. Reprinted by permission of New Directions Publishing Corp.

The Collected Poems of Frank O'Hara, edited by Donald Allen. (C) 1971 by Alfred A. Knopf, Inc. Reprinted by permission of Alfred A. Knopf, Inc.

Paterson, by William Carlos Williams. (C) 1946, I948, 1949, I951, 1 958 , by William Carlos Williams. Reprinted by permission of New Directions Publishing Corp.

The Poems of Emily Dickinson, edited by Thomas H. Johnson, Cambridge, Massachusetts. The Belknap Press of Harvard University Press, (C) 1951, 1955, by the President and Fellows of Harvard College. Reprinted by permission of the publisher and the Trustees of Amherst College.

The publication of this book was assisted by a grant from the Andrew W. Mellon Foundation.

Library of Congress Cataloging in Publication Data

Blasing, Mutlu Konuk, r944-

The art of life.

Bibliography: p.

Includes index.

I. American literature-History and criticism. 2. Autobiography.

I. Title.

PSI69.A95B5 $810^{\prime} .9 \quad 76-20760$

ISBN $0-292-70315-5$

Copyright (C) 1977 by the University of Texas Press

All Rights Reserved

Printed in the United States of America

Set by G \& S Typesetters, Inc.

Illustrations by Ed Lindlof 
To Randy 
This page intentionally left blank. 